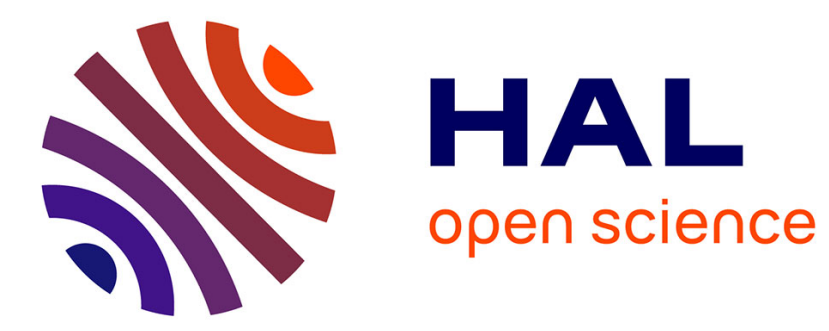

\title{
Third Republic French Philosophy and Ford's Evolving Moral Topologies
}

\author{
Samuel Trainor
}

\section{To cite this version:}

Samuel Trainor. Third Republic French Philosophy and Ford's Evolving Moral Topologies. International Ford Madox Ford Studies, 2011, Ford Madox Ford, France and Provence, 10, pp.85-106. hal-01465058

\section{HAL Id: hal-01465058 https://hal.univ-lille.fr/hal-01465058}

Submitted on 11 Feb 2017

HAL is a multi-disciplinary open access archive for the deposit and dissemination of scientific research documents, whether they are published or not. The documents may come from teaching and research institutions in France or abroad, or from public or private research centers.
L'archive ouverte pluridisciplinaire HAL, est destinée au dépôt et à la diffusion de documents scientifiques de niveau recherche, publiés ou non, émanant des établissements d'enseignement et de recherche français ou étrangers, des laboratoires publics ou privés. 


\title{
THIRD REPUBLIC FRENCH PHILOSOPHY AND FORD'S EVOLVING MORAL TOPOLOGIES
}

\author{
Sam Trainor
}

\section{Unfolding Modernist 'Evolution'}

Proponents of creationism tend to badger scientists to turn up what they call a 'transitional fossil'. Besides projecting cartoon images of fish with legs and fledgling reptiles, their demands are based on a false premise. The near miracles of genetic science notwithstanding, a diachronic quality (like transition) cannot be demonstrated by a synchronic example (like a fossil). Natural selection is not Lamarckian transmutation. For Darwin, no individual organism can undergo or represent evolutionary change. Organisms, with their inherited characteristics, are merely more or less adapted to environments; they survive to pass on those characteristics or they do not. Change is slow and incremental. Speciation occurs over thousands of lifetimes. Transitions are to be found not in a single fossil, but in the fossil record as a whole.

Where the aspects of human culture are concerned - morality, æsthetics, language - the opposite increasingly appears to be true. Change within a generation is the sliding scale of modern history. This kind of evolution is faster and more immediately apparent. As they interact, societies and their qualities change quickly, dividing and merging by turns, generating their own ideological environments. People and their activities - their beliefs and desires - are capable of radical evolution in the course of a single lifetime. We watch it happening. The effect of doing so is to reduce the definitive distance between 'evolution' and 'revolution', and yet the former remains an open-ended curve, where the latter comes full circle. The dynamic and neurotic embrace of a spirit of accelerating evolution might serve as a loose definition of the label 'modernism'. True to form, and much more conclusively than the 'Cambrian explosion', the process that critical history identifies as the onset of modernism has left its share of transitional fossils. French novelists in the first decades of the Third Republic, for example, have deposited a seam of transitional æeuvres in 
the strata of our library shelves: Bourget, Maupassant, Mirbeau, Huysmans....

It is a cliché, and a potentially misleading one, to call Ford Madox Ford 'English literature's best French writer'. The anecdote in his dedication of The Good Soldier to Stella Bowen - about it being 'the best French novel in the English language' - seems ironically apocryphal, not least because the work by Maupassant he cites, Fort comme la mort, is such an odd choice as an exemplary roman. It does have its moments: the ironic epiphany of the painter Bertin seeing a Parisian park 're-varnished' by an artist God as the result of a new tragic passion (of which he is not himself aware) is a bravura moment of æsthetic anti-anagnorisis. One cannot help but have a certain sympathy for Oscar Wilde, however, when he dismisses the novel as a 'lurid little tragedy'. After all, his subsequent détournement of its premise, under the uncompromising gaze of Huysmans's $\grave{A}$ Rebours, produced that immaculate fake portrait of the artist, The Picture of Dorian Gray. The Good Soldier is a different kind of novel to all three and, I would argue, a superior one to either Maupassant's, Wilde's or Huysmans's. In at least one important respect, however, Ford's writing seems to be even more at home in Gallic company than Wilde's. His complete works would not be out of place at all if added to the fossil record of transitional specimens in this pre-modern strata of French literature. To nudge my list into the twentieth century . . . Gide, Proust, Ford. . . .

This essay, then, will seek to do for cultural evolution what it is unreasonable to demand a fossil do for its biological equivalent. It will attempt to demonstrate the salience of Ford's writing as exemplary of modernism's preoccupation with its own transitions (and metatransitions) - with a social, psychological and æsthetic evolution that transforms the very idea of evolution. Ford is not merely a writer in transition, but a writer of, about and via transition. In his fiction, he replays the transformations of thought, society and style he has experienced himself, and he exposes a rare talent for provoking the mimetic reconstruction of analogous experiences in readers' minds.

In order to reveal this quality, the essay will focus on an arbitrary (but crucial) notion in Ford's writing: the idea of a changing 'moral geography' - changing not only in its specific qualities and landscapes, but also in its nature as a concept. In doing so, it will suggest that contemporary French philosophies - via the mechanisms of cultural imitation that one of them describes - had a transformative 
influence on Ford's writing. For the sake of brevity, it will limit references principally to the work of two key writers: Henri Poincaré and Gabriel Tarde. One is a mathematician, the other a sociologist. The natural text of principal reference in Ford's writing will therefore be Parade's End: a series of novels whose mathematician protagonist resists and finally embraces the 'evolution' of local and global moral geographies that occurs during the period that spans the build-up to the Great War, the conflict itself and its fragile aftermath. Ultimately, however, the goal is to show what novelists like Ford contribute to the evolution of a broader philosophical culture, rather than what that philosophical culture contributes to Ford. For that we will have to scratch the surface of how his fiction dramatizes psychological, social and philosophical transitions; and, in passing, how it reads in a contemporary French context.

\section{'The Skeleton Map of a Country': Moral Geographies (Some Do Not ...)}

Between the topographical depictions of the Ordnance Survey (nineteenth century realism at its most precise) and the topological diagram of Harry Beck's 1931 Tube Map (a classic modernist text with innumerable imitators), network maps for systems such as railways and telegraph cables have left their own transitional fossils. They are the result of a system-oriented cartography which reduced to a minimum irrelevant details, whilst foregrounding the routes, the nodes and the organisational logic of their superimposed networks. Unlike Beck's circuit diagram, however, these fin de siècle maps still clung to geodesic projections: representing distances and reproducing the less negligible curves and corners of their intersecting paths. They were not unlike the modern road atlas in conception, yet their intercostal spaces were much less fleshed out. They were known as 'skeleton maps'.

This is what Joyce refers to when he describes Stephen Dedalus - on his return to Dublin as an uneasy flâneur in the second chapter of A Portrait of the Artist as a Young Man:

Dublin was a new and complex sensation [. . . .] In the beginning he contented himself with circling timidly round the neighbouring square or, at most, going half way down one of the side streets but when he had made a skeleton map of the city in his mind he followed boldly one of its central lines until he reached the customhouse. He passed unchallenged among the docks and along the quays wondering at the multitude of corks that lay bobbing on the 
surface of the water in a thick yellow scum, at the crowds of quay porters and the rumbling carts and the ill-dressed bearded policeman. The vastness and strangeness of the life suggested to him by the bales of merchandise stocked along the walls or swung aloft out of the holds of steamers wakened again in him the unrest which had sent him wandering in the evening from garden to garden in search of Mercedes. And amid this new bustling life he might have fancied himself in another Marseille but that he missed the bright sky and the sumwarmed trellises of the wineshops. ${ }^{2}$

This is vintage Joyce. There is an uncanny ambiguity to the irony of the self-conscious cliché. As Dedalus psychologically remaps the labyrinthine city - which his name suggests to be his own design as much as his discovery - Joyce himself retreads the paths of a meticulous internal 'skeleton map' of the urban maze from which he is exiled in space, in time, in culture . . and cannot escape. There are layers of artistic self-admonition superimposed on the effect. The adolescent flight of fancy back to sunny Marseille terraces, and romantic love, is self-evidently doomed to melt and lose its feathers. The fear is that the artistic transcendence of the book's conclusion might be just as doomed if all it offers is a Minotaur imagination that mopes obsessively about the Dublin of its youth. Perhaps this is to read too much of Ulysses into the earlier work. A Portrait . . . makes the point quite clearly, however: the dream of flight contains the labyrinth as much as the labyrinth the dream of flight.

The effect is vintage Joyce, but the style and content reads like vintage Hueffer. Whether intentional on Joyce's part, or not, it would be hard to produce a better pastiche of Ford's writing about London. It is unsurprising, then, that we should find a prototype to Joyce's mental 'skeleton map of the city' in Hueffer's The Soul of London:

Daily details will have merged, as it were, into his bodily functions [. . . . He will have acquired an alertness of eye that will save him from asking his way. On his 'Underground' he will glance at a board rather than enquire of a porter; on busroutes he will catch instinctively, on the advancing and shapeless mass of colour and trade announcements, the small names of taverns, of Crosses, of what were once outlying hamlets; he will have in his mind a rough sketch map of that plot of London that by right of living in he will make his own. ${ }^{3}$

This merging of 'daily details' into the 'bodily functions' is key to the psycho-geographic effect of naturalization Ford describes. The skeleton map on the 'board' is its crucial internode; its engrammatical transposition the moment of metamorphosis. The passage is, however, as referentially unstable and as potentially self-critical as the Joyce. 
This is one of the effects that sets such modernist journeys apart from the flaneur narratives they intertextually retrace. The comparison between the neurological effect upon the rural incomer of travelling the city's intersecting routes and the reconstitution of the city in the writer's mind threatens the authenticity of this vision. It is, of course, the impressionist's immersion of his cognitive functions (and those of the reader) into the remembered 'daily details' of a displaced London (with innumerable literary analogues) that generates this fictional city of textual memory. Ford is not merely speaking in the third person about his own remembered experience of the city, but about the experience of writing (and rereading) the metropolis from memory.

There is a significant play on words here. It is not a 'part' of London - a borough or a suburb - that the incomer 'will make his own', but a 'plot'. Ford understands as well as any writer that story, topography and memory are implicated in each other's matrices. The impressive non-linearity of The Good Soldier is testament to the confidence of a stylist whose strong topographic sense of narrative permits him to lead the reader in a seemingly aimless, but ultimately memorable route through a garden of forking paths. The moral problem of the ménage à cinq in Nauheim is, in narrative terms, something like the mathematical problem of the seven bridges of Königsberg. Ford, like Euler, provides a negative resolution.

Most plots are not so nodally complex, however. They emerge more often from a single route through an environment (spatial or temporal): a commuter's journey, a character's biography. Cognitive psychologists theorize that such simple mental 'plots' are fundamental building blocks of memory. Schank and Abelson's 'Script Theory', for example, relies upon a notion of 'cognitive dependency' that involves a more than analogous relationship between simple narratives of physical movement and what they call 'dynamic memory'. As modern as this work on the internodes of natural and artificial intelligence might seem, it builds upon an architectonics of memory which recalls classical antiquity. Paul Connerton's How Modernity Forgets leads us briskly through the historical construct:

That memory is dependent on topography is an ancient insight. The so-called 'art of memory' was located within the great system of rhetoric that dominated classical culture, was reborn in the Middle Ages, flourished during the Renaissance, and only entered upon its demise during the period from the invention of printing to the turn of the eighteenth century. Cicero gave a succinct statement of its operative principle. 'Persons desiring to train this faculty of 
memory,' he writes, 'must select places and form mental images of the things they wish to remember and store those images in the places, so that the order of the places will preserve the order of the things.' Accordingly, this 'art of memory' was described as a 'method of loci'.

For Cicero these loci are stable abstractions; the 'art' is an artificial trick instigated by the will (albeit one with a neurological basis that modern psychologists explain in terms of the involvement of the hippocampus). Memory in modernist literature (as both theme and structural principle) is, of course, much less stable and controllable. Proust is the most salient example. His loci of memory have a selfgenerative power. It is as if they literally constitute his memory. Marcel does not mentally retread the road past Swann's house in an effort merely to recall the proper order of some abstract set of circumstances that make up the memory of his adolescence. Instead, he finds himself retracing the lost footpaths of his past as if by their own will and according to their cognitive geographies. The patterns of abstraction are more complex, more tenuous and more selfconsciously experienced. A similar preoccupation with a dynamic topographic memory influencing the workings of the (literary) mind is found in Ford. The conversation between Christopher Tietjens and Valentine Wannop in the fog contains numerous examples:

"If," she interrupted, "that was really Gran'fer's Wantways: midland English. 'Vent' equals four cross-roads: high French carrefour. . . . Or, perhaps, that isn't the right word. But it's the way your mind works. ..."

"You have, of course, often walked from your uncle's to Gran'fer's Wantways," Tietjens said, "with your cousins, taking brandy to the invalid in the old toll-gate house. That's how you know the story of Grandfer. You said you had never driven it; but you have walked it. That's the way your mind works, isn't it?" [....]

"Gran'fer's Wantways is six and three-quarters miles from Udimore; Udimore is exactly five from us; total, eleven and three-quarters; twelve and a quarter if you add half a mile for Udimore itself. The name is Udimore, not Uddlemere. Local place-name enthusiasts derive this from 'O'er the mere.' Absurd! Legend as follows: Church builders desiring to put church with relic of St. Rumwold in wrong place, voice wailed: 'O'er the mere.' Obviously absurd! . . . Putrid! 'O'er the' by Grimm's law impossible as 'Udi'; 'mere' not a middle Low German word at all...."

"Why," Tietjens said, "are you giving me all this information?"

"Because," the girl said, "it's the way your mind works [... . It arranges the useless facts in obsolescent patterns $[\ldots]^{6}$ 
The intersection of these two versions of 'the way your mind works' occurs in such a way, and in such a context, as to foreground the awareness of the other's topographic consciousness. This is just as true of the intertextual and historical 'landscape' in Valentine's teasing pastiche of Christopher's way of thinking (which reads like a pedantic note in the annals of a local geographical society) as in Christopher's more literal reference to Valentine's youthful walks. Each is retracing their cognitively formative paths. Their uncanny ability to predict the other's mental 'plots' derives from a mutual sensitivity to the unlikely overlaps of two disparate geographies of thought. The disparity is cultural, political and generational. Valentine refers explicitly to Christopher's 'obsolescent patterns.' It is not merely his sentimental attachment to the rural lanes of the English countryside that is challenged by her complex irony, but the mental structures which they seem to spawn, and to which - despite having intelligence and perspicacity enough to recognise their obsolescence he still clings. It is the perfect example of a collision between the modernist topological (parodic, intertextual) imagination of a progressive bluestocking and the parochial imagination of an Edwardian gentleman. And yet it is also a lovely little scene of teasing flirtation. One that will become the foundational memory of an enduring love affair. Part of Ford's great achievement in these novels is to dramatize the evolution of this love affair as an accommodation of psychological and cultural alterity in various loci (historical and geographical) of a modern European landscape undergoing an analogous evolution.

In order to achieve this, Ford must first re-imagine and re-evoke his pre-war homeland. There is nothing particularly unusual about this in the period. Proust, Musil and Joyce all do the same in their contemporary masterpieces. It is perhaps only Proust's Sodome et Gomorrhe, however, that surpasses Ford's subtle poignancy in reinhabiting the language and modes of thought of the pre-war period in Some Do Not .... The effect relies upon the writer's ability to revisit his earlier writing. This he does as if re-walking the byways of his youth. The celebrated pathfinding scene in the fog mentioned above which ends in a portentous collision between the 'poor old horse' of the past and modernity in the form of Campion's motor car - selfconsciously and self-analytically recalls Ford's most explicit study of memory: No Enemy. This is a work that insists upon the notion of the route-map as the root of recall: not merely in terms of formative content, but also as a structural epistemological image: 
did you ever take a walking tour, or just a long walk and, in bed at the end of the day, perhaps in order to put yourself to sleep, did you ever try to remember every inch of the roads you had covered? Gringoire claimed that in that way he could remember a great many of the roads both of England and France of his boyhood when one walked or cycled a good deal for walking or cycling's sake. Corners of roads, bridges, highways climbing over the forehead of downs - the road out of Bridport, down into Winchester, from Minehead to Lynton; from Calais over the flats to Arras, from Arras to Beauvais; from Blois to Tours; from Amiens to Albert in 1892. . . . By shutting his eyes, or by looking at something blank, like a sheet of paper, or by not really looking at anything at all, he could, he said, evoke a panorama of any of those roads. ${ }^{7}$

Bearing in mind how paradoxical it seems for a traumatised partial amnesiac to claim such a prodigious memory, the doubt expressed by the narrator here is understandable. The paradox is crucial to the effect, however. It is the detachment of Gringoire's superb topographic memory from its emotional, social and spiritual content that the war has effected, leaving his obsessive mind to turn centripetally around four memory landscapes from which there is seemingly no escape. All that remains is the deconstructive metaphor of a remembered landscape as the surface of the rememberer's head: the shell of a brain that can only recall its own exterior by following the roads that are imagined passing over it: "highways climbing over the forehead of downs." Is this remembering or dismemberment?

This literalized concept of topographic psychology is not only implied in No Enemy. Gringoire himself is quite explicit:

'I am not so much concerned to describe these landscapes, or to prove the quality of my memory, as to establish the psychological facts about the other four landscapes.' He had just gone back into memory, without any particular effort without indeed any effort at all, and the roads were there, like a string unwinding from a ball. (NE 30)

'Psychological facts' could just as easily be 'geographical facts', and the narrator walks in step: 'He had just gone back into memory [. . .] and the roads were there'. This was not the first time Ford had written about roads in such an oddly animated manner. Just as Gringoire links the shell-shocked amnesiac Tietjens at the end of Some Do Not . . to Ford's own war-torn memory, No Enemy bridges the gap between his writing on the highways and byways of rural England in Parade's End and in England and the English. In the earlier work, Hueffer had mapped the roads in similarly hybrid terms: 
Level, white and engrossed beneath the sky, as if they too had purposes, as if they too sought some sort of lovers' meeting of their own, where they intersect at the journey's end, the great highways run across the green islands.

The small by-roads, the sunken lanes, all the network of little veins that bring, as it were, tributary drops of blood, go off from side to side as if they were the individuals of a marching body dropping out to do sentry duty in hamlets off the line of march. ${ }^{8}$

This is a fine example of the skeleton map vision: the hybrid of a geodesic image with a corporeal metaphor and a strangely animated portrayal of a dynamic flow between internodes as the primary constitutive quality of a network. It is almost uncannily prescient of Parade's End: the lovers' meeting 'where they intersect at journey's end', 'individuals of a marching body dropping out to do sentry duty in hamlets off the line of march'.

The most unusually Huefferian idea retraced by Tietjens, however, is the notion of an inherent morality of local geography:

each road has its own particular individuality: nay, more, each has its own moral character, its ethics as it were, since what are ethics and morals but the effects of one's attitude upon the beings who come in contact with us? (EE 132)

The illogicality of that 'since' will come as little surprise to most readers of Ford's work. However cogent and heartfelt the assertion, and the rhetorical question that follows, the link between the two is more than tenuous. As a syllogism it would be laughable. Ford is perhaps a rather untidy thinker, but his talent resides in an acute awareness of the dramatic value of untidy thought. Here, the tenuous link between the two ideas mirrors the tenuous link between thought and landscape, between the memory and the place remembered. This skeleton map is therefore particularly flimsy, and seems all the more precious for its fragility. And we can see what he's getting at: roads have their own moral character because those who travel along them construct their moral landscapes from the outcomes of their meetings. The post-war Ford may well have considered such a thought to be embarrassingly quaint. The style ('nay, more') would certainly have seemed that way, but this does not stop him from retracing the same cartography of moral thought in Tietjens's doubtful conclusion at the end of the novel's first section: 
one has to keep on going. . . . Principles are like a skeleton map of a country you know whether you're going east or north.

The knackers cart lumbered round the corner. (PE 144)

It is almost Beckettian black comedy. The term 'skeleton map' is rendered morbidly literal by the proximity of the horse's wounded body. The idea of a topographic network of principles that are mystically attached to a physical locus (with a stable cultural identity) has just been seriously challenged by Valentine Wannop's caricature of Tietjens's obsolescent Toryism. His unconvinced and unconvincing determination to keep on going despite all this is the tragi-comic impetus that will allow the tetralogy to progress through the upheaval of the Great War. We cannot help thinking that it is also Ford making himself keep writing. What ensues is, in a very great part, the dramatic evolution of a stubbornly conservative moral geography under the influence of political and psychological forces of modernity which the war reveals to be irresistible. In its place, a relativist and multidimensional moral topology emerges with its own mimetic stylistics. It will be the task of the rest of this essay to suggest that this evolutionary 'plot' self-consciously revisits the evolution of the topographical elements of Ford's own post-impressionist writing (its styles and themes), and that the most salient philosophical origins of this evolution can be traced to French writers like Poincaré and Tarde.

\section{Finies les parades: psychological geometries (No More Parades)}

The influence of mathematics on modernist literature is perhaps too often taken for granted. The field of theoretical physics seems treacherously familiar to critics. Passing references abound in our metanarratives to things like Einstein's Relativity and Heisenberg's Indeterminacy. Somehow this is matched by a paucity of specifics. There are exceptions, of course, especially in regard to the best known of the canonical modernist novels with a mathematician protagonist: Robert Musil's Der Mann ohne Eigenschaften. ${ }^{9}$ Musil's unfinished masterpiece begs comparison with Parade's End. The fact that the central locus of both groups of novels is a mathematician who is witness to (and in some sense psycho-cultural vessel of) a naïve prewar society that history is about to explode, seems to deserve further investigation. Christopher's marginalised moralistic perspicacity and Ulrich's hollowed-out amoral blindness are opposite sides of the same observational coin. Both reveal the Great War to have been an 
inevitable result of the rapidly evolving cultural and political realities of pre-war Europe, and that the unwitting creation of this violent evolutionary potential had something to do with maths. Beyond comparing Christopher Tietjens to Arthur Marwood, however, Ford scholars tend to overlook (forgive the pun) the mathematical angle.

This is hardly unjustified. Ford appears, on the surface at least, to overlook the mathematics himself. We do get a sense towards the end of Some Do Not . . . that a shell-shocked Tietjens has lost some precious gift when he confesses to an impotence in the face of 'the higher mathematics', but Ford knows better than to insist upon what could be a destabilising irony, given that the author (unlike Musil: a structural expert in both mathematics and irony) had probably never understood it in the first place. The difficult marriage between mathematics and morality is explored in no more depth than the simplistic example of Tietjens's career-ending refusal to massage statistics. On closer inspection, however, Ford is revealed to be a writer intimately acquainted with - and unusually sensitive to - the psychological and social repercussions felt during his lifetime of the most culturally influential development of modern geometry: Henri Poincaré's evocation of relative multi-dimensional space.

Poincaré's was not an arcane idea shared amongst a small côterie of savants. On the contrary, it provided the core thesis of the second volume of his successful popular introduction to modern scientific philosophy, Science et Méthode (1908). The linguistic and metaphorical pertinence to Parade's End of Poincaré's humanist depiction of three-dimensional Euclidean space (that would be implicitly transcended by an elastic multi-dimensional topology), is arresting. It is worth quoting at length:

With each of the blows that may strike us, nature has associated one or several parries [parades] which enable us to protect ourselves [. . . .] It is this complex system of associations, it is this distribution table, so to speak, that is our whole geometry [. . . . It is this multiplicity of parries, [parades] and the resulting coordination, that is space.

Space created in this way is only a small space that extends no further than the reach of my arm; the intervention of memory is necessary to push back its limits [.... We can, if the enemy is too far away, walk up to him first and extend our hand when we are near enough. This is still a parry, [parade] but a longdistance parry [parade]. Furthermore, it is a complex parry, [parade] and the representation of it that we make for ourselves combines the representation of the muscular sensations caused by the movements of the legs, that of the muscular sensations caused by the final movement of the arm, that of the sensations of the 
semi-circular canals, etc. We have, moreover, to make a representation, not of a complex of simultaneous sensations, but of a complex of successive sensations, following one another in a determined order. ${ }^{10}$

Poincaré defines Euclidean space as a cognitive champs de manceuvres (a 'parade ground'), emergent from the physical realities of the human body and designed to delineate the protective enclosure it inhabits. This is described psychologically by means of an imagined parade de parades (a 'parade of parries'). With the addition of memory, it extends to become a set of linear narratives (histoires) of projected sensations and counter-sensations that map the axes of bodily extension and movement. At a stretch, we might even want to call it a 'corporeal textuality' of spacial perception and memory. He goes on, of course, to insist that this crude bodily delimitation of the idea of space can and should be transcended by a multi-dimensional topological imagination.

The brilliance of Poincaré's vulgarizing metaphor for the distribution table of three dimensional co-ordinates resides in its implicit dramatization of the response in the mind of the resistant reader. The text at once posits a revolutionary idea that rocks the stability of an ideological conception of space, and pre-empts the ideological rejection. The threat that this concept posed to a contemporary world view should not be underestimated. It is Copernican in scope. The imaginatively conservative reader might find himself, just like the person described, rehearsing a repertoire of parries (parades) to defend not just his personal space, but the idea of personal space itself, from this devastating conceptual incursion.

Simply put, Poincaré is making the mind-boggling suggestion that we 'think outside the body' ... that we transcend this parade de parades and allow our spatial imagination to open out (to 'evolve', in a geometric sense) into the mutable and multidimensional realm of topological manifolds. In doing so, he provides us with a metaphor for the impact upon the individual consciousness of modernity's philosophical cruxes (emergence, relativity, contingency, pluralism) that seems paradigmatic.

There exists no evidence that Ford was directly influenced by a reading of this passage, nor is it likely that a play on parade was premeditated for the title of the second novel. ${ }^{11}$ Poincaré's relativity of space would, however, have been practically unblockable as a cultural reference for a literate francophile at the beginning of the twentieth century, and Ford's sensitivity to the multilingual and etymological 
complexities of key words like 'parade' is undeniable. ${ }^{12}$ Neither is the influence merely a matter of linguistics or bald intertextuality. The portrayal of Christopher Tietjens in No More Parades is of a precisely analogous territorial consciousness under siege. His is a mental space suffering under a perpetual bombardment - not just of literal ordnance, but of military communications, letters, requests for leave, rumours, accusations, challenges, memories and (most importantly perhaps) threatening ideas and doubts. It is also his internal moral geography (its structure, its locality, even its putative solidity) which is besieged. The principles of his skeleton map - the interdictions of those things that 'some do not do' - massage figures, commit adultery, demand repayment of debts, mistreat a horse, divorce threaten to give way under the bombardment. Moral and physical threats are conflated:

\footnotetext{
Divorce leave! . . Captain McKechnie, second attached ninth Glamorganshires, is granted leave from the $14 / 11$ to the $29 / 11$ for the purpose of obtaining a divorce. . . . The memory seemed to burst inside him with the noise of one of those beastly tin-pot crashes - and it always came when guns made that particular kind of tin-pot crash: the two came together, the internal one and the crash outside. (PE 305)
}

Each of these repercussive 'tin-pot crashes' echoes with moral insubstantiality and political illegitimacy. And yet each one also carries the very real threat - soon to be another strafing memory - of what will happen to that other pathetic cuckold and butt of rumour: O Nine Morgan. Tietjens's bizarrely grim joke that the soldier's head may have been caved in by 'a prize-fighter's fist' ( $P E$ 310), reveals his preoccupation with a sense of impotence in the face of an unending (metaphorical) bombardment of news from home: a home that can no longer be identified as a stable moral landscape, and to which one cannot expect to return. It also grotesquely evokes the impotence of the feeble human body in the face of a literal (modern, technological) bombardment. Unlike the punches of a prize-fighter, these are blows that cannot be parried. It is as true of the psychological and cultural changes with which modernity assails the conservative mind as it is of the bombs that assail the entrenched body: there are no more parries. Even memory carries the threat of dismemberment. One can find relief only in screaming irrationally over the din. 


\section{Social Topologies: (A Man Could Stand Up-)}

The culmination of the assault upon Tietjens's mental and moral space occurs, naturally enough, in the front-line trenches of the tetralogy's third volume. It is here that he uses the most poignantly fragile, futile and fantastic imagery of Euclidean geometry:

\footnotetext{
Something behind his mind forced him to the conviction that, if his head - and of course the rest of his trunk and lower limbs - were suspended by a process of levitation to that distance above the duckboard on which, now, his feet were, he would be in an inviolable sphere. (PE 543)
}

David Trotter's recent examination of Ford's agoraphobia, ${ }^{13}$ as mirrored in Tietjens's fear of the open road in Some Do Not . . . and his withdrawal into himself in No More Parades, would certainly seem pertinent to this fantasy of the 'an inviolable sphere'. Something has changed in this third novel, however. Tietjens has developed a desire to regain the exposed position, to stand again on top of one of the small hills (or terrils) in the area and take the cartographic view. There is a concomitant desire - subtle, nuanced and gradual; but very real - to re-engage with (even to improve) the lines of communication which had previously made him flinch. Ideas, like divorce, which had exploded in him like shells, have been rendered almost plausible by the obliteration of his moral landscape. Thus his agoraphobia begins to evolve into claustrophobia.

The threat of bombardment, however, renders such desires almost unthinkable. Aside from the surrealism of its image of levitation, the above quotation inevitably reminds the reader of poor old $\mathrm{O}$ Nine Morgan. It is thought that cannot be dis(re)membered. Tietjens' mind makes the attachment of trunk and lower limbs to the word 'head' obsessively explicit, as if wishing his head to be down by his feet might tempt cruel fate into a decapitation. The barrage is doing its demoralizing job. Even Tietjens has become superstitious.

Along with 'strafe', the word 'barrage' provides an insistent, threatening back-beat to the second part of A Man Could Stand Up-. It is an interesting word, introduced into English during the Great War, and seemingly definitive of its attritional, static form of warfare. It derives from a French term, cognate (and virtually synonymous) with 'barrier'. The idea of the tir de barrage was to pin the enemy down with a wall of artillery fire through which they could not pass: to stop them from advancing or retreating. Like the verb 'besiege', it develops an internal antithesis in English that brings it almost into the 
realm of Freudian 'primal words'. It means both 'a barrier to escape' and 'an incursion', and as such acts both to delimit the frontiers of occupied territory and to transgress them.

The psychological repercussions of the barrage of modernity upon the individual's mental space are matched, in A Man Could Stand $U p$-, by social repercussions which demand a little further elucidation from contemporary French philosophy. Gabriel Tarde, the Chair of Modern Philosophy at the Collège de France from 1900 until his death in 1904 (when he was replaced by Henri Bergson), had an influence upon modernist thinking that, I would argue, was hugely underestimated throughout a century that tended to represent him merely as the antithesis to Durkheim. Tarde's philosophy was much more original. It was, I would argue, as important as Bergson's. It insisted that psychology and sociology were inextricable: that all thoughts, perceptions and ways of thinking were socially contingent and emergent; and that all societies were constituted as networks of psychological influence.

One need only imagine the impact that ideas like those in the following extract might have had upon early modernist artistic and literary movements (like Ford's impressionism) - and, indeed, note how uncannily pre-emptive they are of postmodernist notions of intertextuality - to accept the potential salience of Tarde's influence upon his contemporary culture:

every act of perception, insofar as it involves an act of memory, which is to say always, relies upon a kind of habit, an unconscious imitation of oneself by oneself [... .] if the idea or the image recollected was originally placed in the mind by a conversation or a reading, if the habitual act has as its origin the vision or the knowledge of another, this memory and this habit are simultaneously social and psychological facts. $^{14}$

Crucially, Tarde's writing provides us with a cogent explanation of how inventions (innovations, new ideas) of the sort found in his own work can worm their way - via communicative pathways that access the inherent imitative ability of the human mind - into the practices and behaviours of an unwitting culture. In his examples - especially of artistic innovation and changes of morality - Tarde is fond of territorial metaphors of defence and siege which recall both Poincaré's depiction of Euclidean space and the 'plot' of Parade's End. We should bear in mind that socio-political metaphors like these 'walled enclosures' are also analogues of individual consciousness for Tarde: 
successive artistic inventions have owed their apparition and their fortune either to the change of ideas, or to the change of customs. Tributes to the elders, family blood-feuds, hospitality, bravery; later: work, probity, respect for livestock, or for another man's field or his wife; later still: patriotism, feudal loyalty, charity, the emancipation of slaves, or the relief of the poor, etc., have brought into being different ages of humanity, just like the Egyptian tomb, the Greek temple or the Gothic cathedral. It has therefore been necessary, at the appearance - in some place, and at the appropriate time - of every new duty [moral imperative], and of every new beauty [artistic style], for a wind of fashion to be raised, so to speak, to disseminate this germ in the world [. . . passing over the walled enclosures of tribes and of cities shut off in their traditional morality and art. Hence the common contradictions between old customs and imported examples, which in part explains the frequently negative character of moral prescriptions and, similarly, of the strictures of taste. Do not kill the conquered enemy to eat him, do not sell one's children, do not kill one's slaves without reason, neither kill nor beat one's women except in cases of infidelity, do not steel the neighbour's ass or his ox etc.; these are the prohibitions, each one very much original and disputed in its time, which make up the best part of the moral code of every people. Their æsthetic code is similarly full of prohibitions. ${ }^{15}$

He portrays morality (and artistic vernacular) as a geographically circumscribed metaphor and the means via which a society's territory is defended. In short, morality and æsthetic taste are both a series of parries. The massive increase in the speed and scope of communication between individuals and groups that characterizes modernity necessarily impacts upon societies' mores and modes of representation. There is a kind of critical limit - achieved when a sense of mutable moral relativism and plurality becomes so unavoidably evident that the geometry of a moral space defended in such a way is rendered untenable - at which point both the content and the nature of a seemingly permanent moral geography are irreversibly destabilised. There are no more parades.

It would be inaccurate to suggest that Tietjens surrenders to such a morally relativist outlook in A Man Could Stand $U p-$. The fact remains, however, that he comes to some kind of an accommodation with a few of the moral proscriptions he has used to defend his mental geography in Some Do Not . . . : capitalism, divorce, an extramarital relationship. All of these adaptations of his moeurs come as the result of a careful re-engagement with the lines of communication (with home, with the army) that he had previously conflated with the paralytically demoralising barrage. 
Central to this effect is an embrace of the social contingency of his individual consciousness. This is particularly noticeable in the way he thinks about - and increasingly like - Valentine Wannop. There is a mimetic influence of these two disparate minds upon each other in the tetralogy which (attractively for readers whose own experience of mimetic response to the linguistic thought of the authorial other is mirrored) forms the bedrock of their redemptive relationship. It allows Tietjens relief from the claustrophobia of his own mental and moral space in the trenches, and offers him the means to go on after the war.

Max Saunders makes the excellent point that Ford after the war becomes, in Bakhtinian terms, a multivocal writer:

Ford responds to the complexity of war-torn Europe not by impressing his own designs upon his material, but by rendering the complexity. His fiction does not work to subordinate everything to his voice (as Dowell tried to, but failed); it recreates the play of conflicting voices, volitions, attitudes and viewpoints. His writing exemplifies what the great Russian critic, Mikhail Bakhtin called 'dialogic' prose. That is, it not only represents the social world by an interplay between different discourses and idioms, but it also investigates how that interplay gets internalized. A novel - especially a novel which recreates a whole society or a historical phase - will, like that society, be an arena across which echo the voices of the characters, and the discourses of the groupings they represent. But in a profound sense so is the individual subject, who also finds himself or herself in that arena. ${ }^{16}$

Part Three of $A$ Man Could Stand Up - is testament to this. Just after the oft-quoted passage in which the Colonel claims the worst thing about the war to be the letters from home, and the tragically absurd tableau of Tietjens buried to his waist in earth like Winnie in Beckett's Happy Days, the reader is treated to a particularly Bakhtinian kind of atonement during the multivocal reunion and celebration of the armistice. It is not merely an aggregate plurality of points of view that characterises this moment of ecstatic communion. There is also a mingling of voices: a mimetic overlap of characters' perspectives:

No one like Fat Man Tietjens. He lounged at the door; easy; benevolent. In uniform now. That was better. An officer, yelling like an enraged Redskin, dealt him an immense blow behind the shoulder blades. He staggered, smiling into the centre of the room. An officer gently pushed her into the centre of the room. She was against him. Khaki encircled them. They began to yell and to prance, most joining hands. Others waved the bottles and smashed underfoot the glasses. Gipsies break glasses at their weddings. (PE 673) 
As the scene climaxes, Tietjens is transformed into an elephant (the animal of memory). The style becomes carnivalesque: 'The man with the eye-glass had stuck a half-crown in his other eye [ . . . ] He was swaying slowly. The elephant! They were dancing! Aranjuez was hanging on to the tall woman like a kid on a telegraph pole' (PE 674).

Bakhtinian, no doubt, but one might also read a good deal of Tarde into the effect. It is social cohesion as mimetic psychological interaction. For Ford, the kind of imitative mental transference that Tarde understands to be the basis of societal construction is the core experience of an enduring love. Consider, for example, how he writes about his lamented friendship with the man upon whom he claimed Tietjens to have been based:

\footnotetext{
I do not know that I ever consulted him [Arthur Marwood] over any of my personal difficulties as I invariably consulted Conrad [. . . . It was much more as if I 'set' my mind by his. If I had personal problems I would go and talk to him about anything else. Then the clarity of the working of his mind had an effect on mine that made me see, if not what was best to do then what would be the most true to myself. ${ }^{17}$
}

This is as close to a perfect example of Tarde's theory of imitation in practice as one might hope for. It is also a nearly paradoxical appeal to something like French existentialist authenticité (or the related, but not identical, German Eigentlichkeit: "what would be the most true to myself') based upon the mimetic reproduction of another person's thinking. If we recall that initial encounter between the two versions of 'the way your mind works(/walks)' in the fog in Some Do Not . . , we can see how this Tardean stylistics of mental mimesis has had a characteristically modernist 'evolutionary' effect on both characters' moral geographies. Their mental maps are no longer restricted to individual space, having merged and multiplied into a mutable and multidimensional social topology.

Our final step will be to see how this evolution of moral geographies across the tetralogy traces a stylistic transformation in the moeurs of Ford's writing itself: from the impressionism of the early work to the nuanced dialogic patterns of The Last Post.

\section{The Aftermath: mimetic syntheses (The Last Post)}

It is a matter of regret, perhaps, that the word 'aftermath' has nothing to do with mathematics. Historically, and literally, it meant the second crop of hay grass that matures in late summer after the first mowing 
(math). It would be ready (and called 'standing hay') at about the same time one harvests cider apples. It is precisely this crop, therefore, through which the crashingly insensitive and risibly pretentious American, Mrs de Bray Pape, rides at the beginning of the tetralogy's last book. The scene may well have been included merely to extend her villainous credentials as the vulgar, anti-natural force of modernity responsible for the end of Groby Great Tree. I doubt we should ignore the subtler symbolism, though. The figurative use of 'aftermath' - to mean the dilapidated state of some temporal or spatial site after a violent upheaval (the upheaval needn't be negatively inflected; it could be a party . . . a parade) - derives from traditional associations of reaping and mortality. Life struggles back, but - initially, at least it is less sweet. ${ }^{18}$

It is the robust and prolifically internodal nature of their rhizomic root structures that allows grasses to produce two crops a year. Gilles Deleuze is credited with developing the idea of the rhizome as a social epistemological image (and antithesis to the hierarchical icon of the [Groby Great] tree). ${ }^{19}$ I would argue, however, that such postmodernist growths are simply 'aftermath' to the first, crop of modernist writings that focused upon the complex and subtle internodes of social thought. The subterranean influence of this network of ideas - in the fiction, for example, of Joyce and Woolf, and in the social science of Gabriel Tarde - never lost its cultural fertility, even after these particular stems were reaped.

Despite its obvious conservatism, The Last Post demonstrates how the mental and moral geography of a group of characters (and of an emergent culture) can be shown to have evolved into a rhizomic topology by means of a stylistics achieves a comparable effect in the reader's mind. It comes as a disappointment to many that we should be alienated from Christopher's thoughts at this point. And yet this is the proscription (abandoning the dominant point of view of the nineteenth century protagonist) that allows the writing to open itself to a mimetically intertwined epistemic geography that will make new life possible in the aftermath of war.

With this one exception, the reader is granted access to all areas: even to the mind of the mute Mark and his previously overlooked petite amie Marie-Léonie. But it is not merely an expansion of the number of mind styles that we experience. The way they interact has also opened out. Whilst the characters obviously retain their own clear points of view and idiolects, the extent to which their thoughts, 
words, memories and opinions mimic and respond to one another is remarkable. The dominant mode of Ford's elastic free indirect style in this novel is flashback as internal memory, prompted and modulated by seemingly irrelevant points of contact or conversation with other characters. This builds on the emergent style of the previous three novels, of course. A mind given to long digressions (narrative, discursive, imagistic) in the context of the interpersonal contacts of their everyday lives is a quality shared by Christopher and Valentine. It is perhaps something like Ford's own experience of life. Often, of course, they are distracted by the memory of the other and of the brief moments they have spent together. Only in The Last Post, however, does this style open itself fully to the wider mimetic networks of a new social psychological topology. Groby Great Tree may be down, but the rhizomic culture it has left behind will nourish the aftermath.

It is no coincidence that a network of loving relationships should make the postwar existence viable for this group of characters. As shown above, the link between love and epistemological mimesis is more than a simple matter of coincidence or empathy for Ford. It is something complex and enduring at which these characters have worked, and at which we see them continually working in their transformative musings upon their lives and their relationships. Alain Badiou, in Eloge de l'amour, insists upon this mental 'work' of love:

There is work involved in love; it is not just a miracle. You have to man the breach, you have to take guard, you have to join up, with yourself and with the other. You have to think, act, transform. And then, yes, as the imminent recompense for this labour, there is happiness. ${ }^{20}$

The imminent recompense for a reader of Parade's End is the sense of one's own mind opened up to new historical possibilities - new moral geographies. It is recompense for the labour involved in re-enacting a radical evolution in social and stylistic mores through which the writer has lived and written. Despite the multiplications and the shifts of focus, at the centre of this matrix we never lose sight of a relationship as apparently unlikely as any Ford himself enjoyed. It is, at every reading, compelling to experience how Valentine and Christopher slowly fall in love on the basis of a mutual appreciation of the depth and value of the same kind of mimetic intellectual relationship as developed between reader and author. Their joint intuition of this love, despite their differences and the tenuous and hostile circumstances their gradual acceptance of its consequences - is genuinely seductive 
of the reader. Desire for the protracted consummation is the motor that drives us (or the horse that draws us) through the landscape of social, cultural, moral, political and psychological change, precisely because it so closely resembles the pace and mode of our own succumbing to the unlikely charms of the old Edwardian novelist: the 'dear old mealsack elephant' . . . the transitional fossil of Anglo-French modernism.

\section{NOTES}

1 Oscar Wilde, 'The Decay of Lying', in De Profundis and Other Writings, ed. Hesketh Pearson, London: Penguin Books, 1986, p. 62.

2 Joyce, A Portrait of the Artist as a Young Man, ed. Jeri Johnson, Oxford: Oxford University Press, 2000, p. 55.

3 Ford Madox Hueffer, The Soul of London, London: Alston Rivers, 1905, p. 9.

4 Schank, R. C. \& Abelson, R., Scripts, Plans, Goals, and Understanding, Hillsdale, NJ: Earlbaum Assoc. 1977. Schank, R.C., Dynamic Memory: A Theory of Reminding and Learning in Computers and People, Cambridge: Cambridge University Press, 1982.

5 Paul Connerton, How Modernity Forgets, Cambridge: Cambridge University Press, 2009, pp. 4-5.

6 Ford, Parade's End, London: Penguin, 2002 - henceforth PE; pp. 134-5.

7 Ford, No Enemy, ed. Paul Skinner, Manchester: Carcanet, 2002 - henceforth NE; pp. 26-7.

8 Ford Madox Hueffer, England and the English, New York: McClure, Phillips, 1907 - henceforth $E E ;$ p. 154.

9 Notable recent exceptions beyond the realm of Musil studies include Daniel Albright's Quantum Poetics (Cambridge: Cambridge University Press, 1997), Michael Whitworth's Einstein's Wake (Oxford: Oxford University Press, 2002) and Allen Thiher's Fiction Refracts Science (University of Missouri Press, 2005). Jeremy Gray's Plato's Ghost (Princeton University Press 2009) is remarkable in taking the opposite perspective, i.e. mathematics in the context of modernist literature and art.

10 Henri Poincaré, Science et méthode, Paris: Flammarion, (1908) 1924, pp. 105-8. Tome II Chap. 1 'La Relativité de l'Espace' II-III. All translations of quotations from the French are my own. References are to French originals.

11 It is worth pointing out that the title of the 1933 French translation of the novel by Fernande Bogatyreff and Georges Pillement seems even more pertinent to the Poincaré quotation than the original English. Finies les parades could mean not simply 'the parades/parries are finished' but also that they are finite.

12 See, for example, his extended riff on 'felicity' in Between St. Dennis and St. George, London: Hodder and Stoughton, 1915), pp. 203-5. It begins like this: "Un vieux piano supportait, sous un baromètre, un tas pyramidal de boîtes en 
carton." [. . . .] it is perhaps only Flaubert who ever paid sufficient attention even to the French language to reach its thorough understanding, and thus to appreciate the value to the world of the mind of Félicité, who for more than forty years was the servant of Mme Aubain of Pont-l'Evêque'. Oddly, the quotation from 'Un Coeur Simple' here is precisely the same one used by Roland Barthes in his demolition of realist stylistics: 'L'Effet du Réel', Communications, no. 11 (1968), 84-9. Ford's use of it actually manages to do a better job of destabilizing the precarious pyramid (that glaring symbol of the moral geometry of freemasonry) of Flaubert's representation of France. Ford's vision of the country's happiest quality - 'felicity', itself a kind of realism - seems to emerge exclusively from a whimsical play on words found in a work of fiction. This implicitly calls into question the attempts of realist fiction to hold at bay precisely this kind of ludic imagination. The problem is compounded by the wholesale re-use of the chapter in the postwar A Mirror to France, as if Ford's rather desperate (and already longsince outdated) plea in 1915 that France should 'never change' had somehow allowed its culture to fend off the transformative effects of the war.

13 David Trotter 'Ford Against Lewis and Joyce', in Ford Madox Ford: Literary Networks and Cultural Transformations, ed. Andrzej Gasiorek and Daniel Moore, Amsterdam and New York: Rodopi, 2008, International Ford Madox Ford Studies 7, pp. 131-49.

14 Gabriel Tarde (1890), les Lois de l'imitation, Paris: éditions Kimé, 1993, p. 81-2.

15 Ibid., p. 375-6.

16 Max Saunders, Ford Madox Ford: A Dual Life, 2 vols, Oxford: Oxford University Press, 1996, vol. 2, p. 211.

17 Ford, Return to Yesterday, London: Gollancz, 1931, p. 375.

18 It is probably no coincidence that Mrs de Bray Pape's own self-identification as a second growth is so patently absurd. She believes herself to be the reincarnation of Madame de Maintenon. Her grasp of history is feeble, to say the least. And this has something to do with her apparent lack of pathos and her insensitivity to the other characters' concerns and ways of thinking.

19 Deleuze and Guattari, Mille Plateaux, Paris: Les Editions de minuit, 1980.

20 Alain Badiou, Eloge de l'amour, Paris: Flammarion, 2009, p. 70. 